\title{
FAKTOR-FAKTOR YANG BERHUBUNGAN DENGAN \\ KEIKUTSERTAAN MENJADI PESERTA JAMINAN KESEHATAN NASIONAL (JKN) DI WILAYAH PUSKESMAS KEMBANG SERI BENGKULU TENGAH
}

\section{The Factors Associated with Participation of Being Member of National Health Insurance in Working Area of Kembang Seri Public Health Center Bengkulu Tengah}

\author{
Vike Pebri Giena $^{1}$, Nikki Sulastry ${ }^{1}$, Buyung Keraman ${ }^{2}$ \\ ${ }^{1}$ Program Studi Ilmu Keperawatan STIKES Tri Mandiri Sakti Bengkulu \\ ${ }^{2}$ Program Studi Matematika Fakultas MIPA Universitas Bengkulu \\ E-mail: vikepebrigiena@gmail.com
}

\begin{abstract}
ABSTRAK
Jaminan Kesehatan Nasional (JKN) merupakan bagian dari Sistem Jaminan Sosial Nasional (SJSN) yang diselenggarakan oleh Badan Penyelenggara Jaminan Sosial (BPJS) dengan tujuan untuk memenuhi kebutuhan dasar kesehatan masyarakat yang layak yang diberikan kepada setiap orang yang telah membayar iuran atau iurannya dibayar oleh Pemerintah. Tujuan penelitian ini adalah untuk mempelajari faktor-faktor yang berhubungan dengan keikutsertaan menjadi peserta Jaminan Kesehatan Nasional (JKN) di Wilayah Puskesmas Kembang Seri Bengkulu Tengah. Desain penelitian ini adalah Cross Sectional. Populasi dalam penelitian ini adalah seluruh warga yang berada di wilayah Puskesmas Kembang Seri sebanyak 8436 orang. Sampel diambil menggunakan teknik Accidental Sampling berdasarakan kriteria inklusi dan eksklusi besar sampel 96 orang. Teknik analisis data dilakukan dengan analisis univariat dan bivariat dengan uji Chi-Square dan uji Contingency Coefficient. Hasil uji penelitian ini didapatkan 80 orang $(83,3 \%)$ ikut serta dalam JKN, 16 orang $(16,7 \%)$ tidak ikut serta dalam JKN, ada hubungan antara tingkat pendidikan dengan keikutsertaan Jaminan Kesehatan Nasional dengan keeratan sedang. Ada hubungan antara pengetahuan dengan keikutsertaan Jaminan Kesehatan Nasional dengan keeratan sedang. Ada hubungan pekerjaan dengan keikutsertaan Jaminan Kesehatan Nasional dengan keeratan sedang. Ada hubungan pendapatan dengan keikutsertaan Jaminan Kesehatan Nasional dengan keeratan lemah. Diharapkan Badan Penyelenggara Jaminan Sosial (BPJS) untuk meningkatkan pengawasan dan kerjasama dengan pihak Puskesmas guna meningkatkan pengetahuan masyarakat tentang Jaminan Kesehatan Nasional $(J K N)$.
\end{abstract}

Kata Kunci : JKN, pekerjaan, pendapatan, pengetahuan, tingkat pendidikan

\section{ABSTRACT}

National Health Insurance (JKN) is part of the Social Security System National (SJSN) organized by the Social Security Organizing Agency (BPJS) with the goal of meeting the basic needs of proper public health given to each people who have paid contributions or whose contributions have been paid by the Government. 
The aim of this study was to determine factors associated with participation of being member of Nasional Health Insurance in Area of Puskesmas Kembang Seri Bengkulu Tengah. This study used Cross Sectional design. Populasi in this study were all residents in Area of Puskesmas Kembang Seri with the amount of 8436 people. Sampling technique in this study used Accidental Sampling base on inclusion and exclusion criteria with the amount samples of 96 people. Data analysis in this study used univariate analysis and bivariate analysis with ChiSquare test and Contingency Coefficient test. The results of this study found 80 people $(83,3 \%)$ participated in JKN, 16 people $(16,7 \%)$ did not participated in $J K N$, there is significant relationship between education level with participation of being member of Nasional Health Insurance with moderate category relationship. There is significant relationship between knowledge with participation of being member of Nasional Health Insurance with moderate category relationship. There is significant relationship between occupations with participation of being member of Nasional Health Insurance with moderate category relationship. There is significant relationship between incomes with participation of being member of Nasional Health Insurance with weak category relationship. It is expected that the Social Security Organizing Agency (BPJS) will increase supervision and collaboration with the Puskesmas to increase public knowledge about the National Health Insurance (JKN).

Keywords: education level, income, JKN, knowledge, occupation

\section{A. Pendahuluan}

Setiap penduduk di suatu negara membutuhkan perlindungan kesehatan sebagai kebutuhan dasar kehidupan. Salah satu bentuk perlindungan tersebut adalah Jaminan Kesehatan. Jaminan Kesehatan adalah jaminan berupa perlindungan kesehatan agar peserta memperoleh manfaat perlindungan dalam memenuhi kebutuhan dasar kesehatan yang diberikan kepada setiap orang yang telah membayar iuran atau iurannya dibayar pemerintah. Undang-Undang Nomor 40 Tahun 2004 tentang SJSN disebutkan bahwa program Jaminan Kesehatan Nasional (JKN) adalah suatu program pemerintah dan masyarakat dengan tujuan memberikan kepastian jaminan kesehatan yang menyeluruh bagi setiap rakyat Indonesia agar penduduk Indonesia dapat hidup sehat, produktif dan sejahtera. (Putri, 2014)
Salah satu masalah yang harus dihadapi dalam pembangunan kesehatan sekarang ini adalah terjadinya transisi epidemiologi dari penyakit menular (PM) menjadi penyakit tidak menular (PTM). Berdasar data dari Global Health Observatory (GHO) oleh WHO 2018, Non Communicable Disease (NCD) atau penyakit tidak menular (PTM) seperti penyakit jantung, stroke, kanker, diabetes dan penyakit paruparu kronik, secara kolektif bertanggung jawab atas hampir $70 \%$ dari semua kematian didunia. Beberapa penyakit tidak menular utama yang ada di dunia antara lain penyakit jantung iskemik dan stroke adalah pembunuh terbesar di dunia, bertanggung jawab atas 15,2 juta kematian, penyakit paru obstruktif kronis merenggut 3,0 juta jiwa pada tahun 2016, sedangkan kanker paru-paru menyebabkan 1,7 juta kematian, diabetes melitus membunuh 1,6 juta orang tahun 2016, 
naik dari kurang dari 1 juta pada tahun 2000 (WHO, 2016).

Berlandaskan hasil Riset Kesehatan Dasar (Riskesdas) 2018 juga telah terjadi pergeseran kecenderungan penyakit yang menyebabkan kematian di Indonesia dari penyakit menular menjadi penyakit tidak menular atau penyakit kronis. Riskesdas 2018 menunjukkan prevalensi penyakit tidak menular mengalami kenaikan jika dibandingkan dengan Riskesdas 2013, antara lain kanker, stroke, penyakit ginjal kronis, diabetes melitus, dan hipertensi. Prevalensi kanker naik dari 1,4 permil (Kemenkes RI, 2013) menjadi 1,8 permil; prevalensi stroke naik dari 7 permil menjadi 10,9 permil; dan penyakit ginjal kronik naik dari 2 permil menjadi 3,8 permil. Berdasarkan pemeriksaan gula darah, diabetes melitus naik dari $6,9 \%$ menjadi $8,5 \%$ dan hasil pengukuran tekanan darah, hipertensi naik dari $25,8 \%$ menjadi $34,1 \%$. Kenaikan prevalensi penyakit tidak menular ini berhubungan dengan pola hidup, antara lain merokok, konsumsi minuman beralkohol, aktivitas fisik, serta konsumsi buah dan sayur (Kemenkes RI, 2018).

Masalah peningkatan jumlah kasus penyakit tidak menular memberikan dampak negatif termasuk sisi ekonomi dan produktivitas sumber daya manusia. Selain itu peningkatan prevalensi kasus penyakit tidak menular juga menyebabkan meningkatnya pembiayaan kesehatan. Dari hasil publikasi oleh World Economic Forum pada bulan April 2015 menunjukkan besaran potensial yang harus ditanggung di Indonesia akibat penyakit tidak menular periode 2012 hingga 2030 diperkirakan mencapai USD 4,47 triliun atau sebesar 5,1 kali GDP. Semakin berkembang zaman untuk memelihara kesehatan membutuhkan biaya yang mahal. Masyarakat yang sudah terlindungi oleh jaminan kesehatan dapat menekan pengeluaran untuk biaya pengobatan dan penyembuhan pada layanan kesehatan. Oleh karena itu, program ini diharapkan dapat meningkatkan umur harapan hidup masyarakat Indonesia dan menurunkan angka kematian, serta memfasilitasi peserta yang memiliki masalah-masalah kesehatan lainnya. (World Economic Forum, 2015).

Berdasarkan data BPJS

Kesehatan, sampai dengan Desember 2018 kepersertaan program JKN di seluruh Indonesia yang telah terdaftar adalah berjumlah 207.834.315 peserta, yang terdiri dari peserta Penerima Bantuan Iuran (PBI) berjumlah 92.469.046 peserta. Peserta Bukan Penerima Bantuan Iuran (non PBI) berjumlah peserta 53.019.381 peserta terdiri atas Pekerja Penerima Upah (PPU) berjumlah 17.218.712 peserta, Pekerja Bukan Penerima Upah (PBPU) berjumlah 30.656.096 peserta, dan Bukan Pekerja (BP) berjumlah 5.144.573 peserta. Jika dibandingkan dengan total jumlah penduduk Indonesia sekitar 265 juta jiwa maka masih ada 57 juta jiwa yang tidak terdaftar sebagai peserta JKN (BPJS Kesehatan, 2018).

Berdasarkan data semester I 2017 dari Dinas Kependudukan dan Catatan Sipil (Dukcapil) Provinsi Bengkulu, jumlah penduduk Bengkulu mencapai 1.145.827 jiwa, sementara jumlah peserta JKN-KIS di Bengkulu baru mencapai 849.191 jiwa. Dari data tersebut di Bengkulu Tengah peserta yang terdaftar JKN 65.064 jiwa dari jumlah penduduk 108.889 sekitar 43.000 jiwa belum terdaftar sebagai peserta JKN. Data tersebut menunjukkan masih rendahnya keikutsertaan Jaminan Kesehatan 
Nasional oleh masyarakat (BPS Kabupaten Bengkulu Tengah, 2018).

Berdasarkan studi pendahuluan yang dilakukan peneliti di Puskesmas, data yang didapat dari pegawai Puskesmas Kembang Seri dari aplikasi pelayanan BPJS Puskesmas didapat jumlah peserta JKN yang terdaftar per Desember untuk puskesmas kembang seri yaitu sekitar 3641 peserta dari Jumlah penduduk di wilayah kerja Puskesmas Kembang seri sekitar 8436 jiwa. Data tersebut menunjukkan bahwa masih banyaknya penduduk belum ikutserta dalam Jaminan Kesehatan Nasional. Hal tersebut karena kurangnya pengetahuan tentang Jaminan Kesehatan Nasional masih terbatas. Hal tersebut berdampak pada ketidakyakinan mereka untuk mengikuti Jaminan Kesehatan Nasional (Puskesmas Kembang Seri, 2018).

Penelitian yang dilakukan Purwaningsih (2016) yang membahas faktor-faktor yang berhubungan dengan keikutsertaan masyarakat dalam JKN. Hasil penelitian didapatkan responden yang berpengetahuan baik (84\%) mayoritas mengikuti program JKN. Masyarakat dengan pengetahuan baik tentang JKN didukung dengan penghasilan yang cukup akan mempertimbangan dengan baik untuk mengikuti JKN, sedang masyarakat dengan pengetahuan kurang ataupun baik tidak didukung dengan penghasilan yang cukup mereka akan memperhitungkan untuk mengikuti JKN karena penghasilan akan lebih diutamakan untuk kebutuhan sehari-hari dari pada mengikuti JKN.

Penelitian yang juga dilakukan Puspitasari (2017) tentang faktor yang mempengaruhi partisipasi kepesertaan Jaminan kesehatan nasional pada pekerja bukan penerima upah di desa kasiyan timur didapatkan hasil variabel pendidikan mempunyai pengaruh terhadap partisipasi kepesertaan JKN pada PBPU sedangkan jumlah anggota keluarga tidak mempunyai pengaruh terhadap partisipasi kepesertaan JKN pada PBPU. Variabel pengetahuan dan pendapatan mempunyai pengaruh terhadap partisipasi kepesertaan JKN pada PBPU sedangkan akses pada pelayanan dan dukungan sosial tidak mempunyai pengaruh terhadap partisipasi kepesertaan JKN pada PBPU.

Pencapaian Universal Health Coverage (UHC) melalui program JKN diharapkan mampu meningkatkan derajat kesehatan masyarakat. Hal ini dapat tercapai apabila semua masyarakat mendaftarkan diri menjadi peserta JKN, khususnya bagi masyarakat yang tidak masuk sebagai peserta JKN PBI maupun peserta JKN non PBI PPU. Akan tetapi, ada beberapa faktor yang dimungkinkan dapat mempengaruhi masyarakat untuk mendaftarkan diri sebagai peserta JKN. Berdasarkan dari permasalahan di atas, peneliti tertarik untuk mengetahui faktor yang berhubungan dengan keikutsertaan menjadi peserta JKN di wilayah kerja Puskesmas Kembang seri Kec. Talang Empat Kab. Bengkulu Tengah.

Rumusan masalah dalam penelitian ini adalah "Apakah faktorfaktor yang berhubungan dengan keikutsertaan menjadi peserta Jaminan Kesehatan Nasional (JKN) di Wilayah Puskesmas Kembang Seri Bengkulu Tengah?. Tujuan penelitian ini adalah untuk mempelajari faktor-faktor yang berhubungan dengan keikutsertaan menjadi peserta Jaminan Kesehatan Nasional (JKN) di Wilayah Puskesmas Kembang Seri Bengkulu Tengah. 


\section{B. Metode Penelitian}

Penelitian ini dilakukan pada bulan April-Mei 2019 di Puskesmas Kembang Seri Kabupaten Bengkulu Tengah. Metode yang digunakan dalam penelitian ini adalah Cross Sectional. Populasi dalam penelitian ini adalah seluruh warga yang berada diwilayah Puskesmas Kembang Seri yaitu sebanyak 8436 orang. Teknik pengambilan sampel dalam penelitian ini menggunakan teknik Accidental sampling berdasarkan kriteria inklusi dan ekslusi. Teknik pengumpulan data yang digunakan dalam penelitian ini adalah menggunakan kuesioner. Teknik analisa data menggunakan analisis univariat dan analisis bivariat, analisis bivariat bertujuan untuk menguji pengaruh antara variabel independent (tingkat pendidikan, pengetahuan, pekerjaan, pendapatan) dengan variabel dependent (Keikutsertaan Jaminan Kesehatan Nasional) dengan menggunakan $U j i$ Chi- Square $\left(\chi^{2}\right)$ dengan tingkat kepercayaan $95 \%(\alpha=0,05)$ dan untuk mengetahui besar hubungan menggunakan Uji Contingency Coefficient (C).

\section{Hasil Penelitian}

\section{Analisis Univariat}

Analisis ini dilakukan untuk mengetahui sebaran karakteristik responden berdasarkan variabelvariabel yang diteliti, yaitu

Tabel 1

Distribusi Responden Berdasarkan Tingkat Pendidikan di Puskesmas Kembang Seri

\begin{tabular}{ccc}
\hline Tingkat Pendidikan & Frekunsi $(\mathrm{n})$ & Persentase $(\%)$ \\
\hline Dasar & 14 & 14,6 \\
Menengah & 74 & 77,1 \\
Tinggi & 8 & 8,3 \\
\hline Total & 96 & 100,0 \\
\hline
\end{tabular}

Berdasarkan tabel menunjukkan $(8,3 \%)$ memiliki tingkat pendidikan bahwa sebagian besar responden tinggi dan 14 orang $(14,6 \%)$ memiliki memiliki tingkat pendidikan menengah tingkat pendidikan rendah. sebanyak 74 orang $(77,1 \%), 8$ orang

Tabel 2

Distribusi Responden Berdasarkan Pengetahuan di Puskesmas Kembang Seri

\begin{tabular}{ccc}
\hline \multicolumn{3}{c}{ Puskesmas Kembang Seri } \\
\hline Pengetahuan & Frekunsi (n) & Persentase $(\%)$ \\
Baik & 61 & 63,5 \\
Cukup & 25 & 26,0 \\
Kurang & 10 & 10,4 \\
\hline Total & 96 & 100.0 \\
\hline
\end{tabular}

Dari tabel di atas dapat dilihat bahwa pengetahuan responden tentang JKN baik, sebanyak 61 orang $(63,5 \%)$ memiliki pengetahuan yang baik tentang JKN, 25 orang $(26,0 \%)$ yang memiliki pengetahuan yang cukup dan sebanyak 10 orang $(10,4 \%)$ memiliki pengetahuan kurang baik tentang JKN. 
Tabel 3

Distribusi Responden Berdasarkan Pekerjaan di

Puskesmas Kembang Seri

\begin{tabular}{ccc}
\hline Pekerjaan & Frekunsi (n) & Persentase $(\%)$ \\
\hline Ekonomi Tinggi & 6 & 6,2 \\
Ekonomi Sedang & 72 & 75,0 \\
Ekonomi Rendah & 18 & 18,8 \\
\hline Total & 96 & 100.0 \\
\hline
\end{tabular}

Dari tabel menunjukkan bahwa pekerjaan dengan status ekonomi tinggi sebagian responden menunjukkan dan 18 orang $(18,8 \%)$ menunjukkan pekerjaan dengan status ekonomi pekerjaan dengan status ekonomi sedang yaitu sebanyak 72 orang rendah. $(75,0 \%), 6$ orang $(6,2 \%)$ menunjukkan

Tabel 4

Distribusi Responden Berdasarkan Pendapatan di Puskesmas Kembang Seri

\begin{tabular}{ccc}
\hline Pendapatan & Frekunsi $(\mathrm{n})$ & Persentase $(\%)$ \\
\hline Tinggi & 24 & 25,0 \\
Sedang & 61 & 63,5 \\
Rendah & 11 & 11,5 \\
\hline Total & 96 & 100,0 \\
\hline
\end{tabular}

Dari tabel di atas menunjukkan dari 96 orang, tingkat pendapatan tinggi sebanyak 24 orang $(25,0 \%), 61$ orang $(63,5 \%)$ memiliki pendapatan sedang dan 11 orang $(11,5 \%)$ memiliki pendapatan rendah.

Tabel 5

Distribusi Responden Berdasarkan Keikutsertaan JKN di Puskesmas Kembang Seri

\begin{tabular}{ccc}
\hline Keikutsertaan JKN & Frekunsi (n) & Persentase (\%) \\
\hline Tidak Ikut Serta & 16 & 16,7 \\
Ikut Serta & 80 & 83,3 \\
\hline Total & 96 & 100,0 \\
\hline
\end{tabular}

Dari tabel di atas menunjukkan dari 96 orang, sebanyak 16 orang $(16,7 \%)$ tidak ikutserta dalam JKN. Dan 80 orang $(83,3 \%)$ ikut serta JKN.

\section{Analisis Bivariat}

Analisis ini untuk mengetahui hubungan antara tingkat pendidikan, pengetahuan, pekerjaan, pendapatan dengan keikutsertaan JKN di Puskesmas Kembang Seri. Untuk mengetahui hubungan antara variable

independen dengen variable dependen dilakukan dalam bentuk tabulasi silang (crosstab) dengan menggunakan uji Chi-Square $\left(\chi^{2}\right)$ dengan tingkat kepercayaan $95 \% \quad(\alpha=0,05)$, untuk mengetahui keeratan hubungan 
digunakan uji Contigency Coefficient (C).

Tabel 6

Hubungan Tingkat Pendidikan dengan Keikutsertaan JKN di Wilayah Kerja Puskesmas Kembang Seri

\begin{tabular}{|c|c|c|c|c|c|c|c|c|c|}
\hline \multirow{3}{*}{$\begin{array}{c}\text { Tingkat } \\
\text { Pendidikan }\end{array}$} & \multicolumn{4}{|c|}{ Keikutsertaan JKN } & & & \multirow{3}{*}{$\chi^{2}$} & \multirow{3}{*}{$p$} & \multirow{3}{*}{$\mathrm{C}$} \\
\hline & \multicolumn{2}{|c|}{$\begin{array}{c}\text { Tidak Ikut } \\
\text { Serta }\end{array}$} & \multicolumn{2}{|c|}{ Ikut Serta } & \multicolumn{2}{|c|}{ Total } & & & \\
\hline & $\mathrm{F}$ & $\%$ & $\mathrm{~F}$ & $\%$ & $\mathrm{~F}$ & $\%$ & & & \\
\hline Dasar & 6 & 42,9 & 8 & 57,1 & 14 & 100 & & & \\
\hline Menengah & 10 & 13,5 & 64 & 86,5 & 74 & 100 & 9044 & 0,011 & 028 \\
\hline Tinggi & 0 & 0 & 8 & 100 & 8 & 100 & 9,044 & 0,011 & 0,293 \\
\hline Total & 16 & 16,7 & 80 & 83,3 & 96 & 100 & & & \\
\hline
\end{tabular}

Hasil uji Pearson Chi-Square pendidikan dengan keikutsertaan didapat yaitu terdapat hubungan yang menjadi peserta Jaminan Kesehatan signifikan dimana nilai $\quad \mathrm{p}$-value $=$ Nasional di Puskesmas Kembang Seri 0,011 0,05 berarti signifikan, maka Bengkulu Tengah. Hasil uji Ho ditolak dan Ha diterima. Jadi Ada Contingency Coefficient menunjukan hubungan yang signifikan antara kategori hubungan sedang.

Tabel 7

Hubungan Pengetahuan dengan Keikutsertaan JKN di Wilayah Kerja Puskesmas Kembang Seri

\begin{tabular}{|c|c|c|c|c|c|c|c|c|c|}
\hline \multirow{3}{*}{ Pengetahuan } & \multicolumn{4}{|c|}{ Keikutsertaan JKN } & & & \multirow{3}{*}{$\chi^{2}$} & \multirow{3}{*}{$p$} & \multirow{3}{*}{$\mathrm{C}$} \\
\hline & \multicolumn{2}{|c|}{$\begin{array}{c}\text { Tidak Ikut } \\
\text { Serta } \\
\end{array}$} & \multicolumn{2}{|c|}{ Ikut Serta } & \multicolumn{2}{|c|}{ Total } & & & \\
\hline & $\mathrm{F}$ & $\%$ & $\mathrm{~F}$ & $\%$ & $\mathrm{~F}$ & $\%$ & & & \\
\hline Baik & 9 & 14,8 & 52 & 85,2 & 61 & 100 & & & \\
\hline Cukup & 2 & 8 & 23 & 92 & 25 & 100 & & & \\
\hline Kurang & 5 & 50 & 5 & 50 & 10 & 100 & 9,513 & 0,009 & 0,300 \\
\hline Total & 16 & 16,7 & 80 & 83,3 & 96 & 100 & & & \\
\hline
\end{tabular}

Hasil uji Pearson Chi-Square didapat yaitu terdapat hubungan yang signifikan dimana nilai $\mathrm{p}$-valu $=0,009<$ 0,05 berarti signifikan, maka Ho ditolak dan $\mathrm{Ha}$ diterima. Jadi Ada hubungan yang signifikan antara pengetahuan dengan keikutsertaan menjadi peserta Jaminan Kesehatan Nasional di Puskesmas Kembang Seri Bengkulu Tengah. Sedangkan hasil uji Contingency Coefficient menunjukan kategori hubungan sedang. 
Tabel 8

Hubungan Pekerjaan dengan Keikutsertaan

JKN di Wilayah Kerja Puskesmas Kembang Seri

\begin{tabular}{|c|c|c|c|c|c|c|c|c|c|}
\hline \multirow{3}{*}{ Pekerjaan } & \multicolumn{4}{|c|}{ Keikutsertaan JKN } & & & \multirow{3}{*}{$\chi^{2}$} & \multirow{3}{*}{$p$} & \multirow{3}{*}{$\mathrm{C}$} \\
\hline & \multicolumn{2}{|c|}{$\begin{array}{l}\text { Tidak Ikut } \\
\text { Serta }\end{array}$} & \multicolumn{2}{|c|}{ Ikut Serta } & \multicolumn{2}{|c|}{ Total } & & & \\
\hline & $\mathrm{F}$ & $\%$ & $\mathrm{~F}$ & $\%$ & $\mathrm{~F}$ & $\%$ & & & \\
\hline Ekonomi Tinggi & 4 & 66,7 & 2 & 33,3 & 6 & 100 & & & \\
\hline Ekonomi Sedang & 12 & 16,7 & 60 & 83,3 & 72 & 100 & 14400 & $\Omega 0 \cap 1$ & 0261 \\
\hline Ekonomi Rendah & 0 & 0 & 18 & 100 & 18 & 100 & 14,400 & 0,001 & 0,561 \\
\hline Total & 16 & 16,7 & 80 & 83,3 & 96 & 100 & & & \\
\hline
\end{tabular}

Hasil uji Pearson Chi-Square pekerjaan dengan keikutsertaan didapat yaitu terdapat hubungan yang menjadi peserta Jaminan Kesehatan signifikan dimana nilai $\quad \mathrm{p}$-value $=$ Nasional di Puskesmas Kembang Seri 0,001 $<0,05$ berarti signifikan, maka Bengkulu Tengah. Sedangkan hasil uji Ho ditolak dan Ha diterima. Jadi Ada Contingency Coefficient menunjukan hubungan yang signifikan antara kategori hubungan sedang.

Tabel 9

Hubungan Pendapatan dengan Keikutsertaan JKN di Wilayah Kerja Puskesmas Kembang Seri

\begin{tabular}{|c|c|c|c|c|c|c|c|c|c|}
\hline \multirow{3}{*}{ Pendapatan } & \multicolumn{4}{|c|}{ Keikutsertaan JKN } & \multirow{2}{*}{\multicolumn{2}{|c|}{ Total }} & \multirow{3}{*}{$\chi^{2}$} & \multirow{3}{*}{$p$} & \multirow{3}{*}{$\mathrm{C}$} \\
\hline & \multicolumn{2}{|c|}{$\begin{array}{c}\text { Tidak Ikut } \\
\text { Serta } \\
\end{array}$} & \multicolumn{2}{|c|}{ Ikut Serta } & & & & & \\
\hline & $\mathrm{F}$ & $\%$ & $\mathrm{~F}$ & $\%$ & $\mathrm{~F}$ & $\%$ & & & \\
\hline Tinggi & 8 & 33,3 & 16 & 66,7 & 24 & 100 & & & \\
\hline Sedang & 8 & 13,1 & 53 & 86,9 & 61 & 100 & 7554 & 20? 0 & ת \\
\hline Rendah & 0 & 0 & 11 & 100 & 11 & 100 & 1,554 & $0,0<3$ & $0,2 / 0$ \\
\hline Total & 16 & 16,7 & 80 & 83,3 & 96 & 100 & & & \\
\hline
\end{tabular}

Hasil uji Pearson Chi-Square didapat yaitu terdapat hubungan yang signifikan dimana nilai $\quad \mathrm{p}$-value $=$ $0,023<0,05$ berarti signifikan, maka Ho ditolak dan Ha diterima. Jadi Ada hubungan yang signifikan antara pendapatan dengan keikutsertaan menjadi peserta Jaminan Kesehatan Nasional di Puskesmas Kembang Seri Bengkulu Tengah. Sedangkan hasil uji Contingency Coefficient menunjukan kategori hubungan lemah.

\section{Pembahasan}

Berdasarkan hasil di atas mengenai hubungan pendidikan dengan keikutsertaan JKN menunjukkan bahwa dari total sampel 96 orang di Puskesmas Kembang Seri terdiri dari 14 orang memiliki pendidikan dasar terdapat 6 orang tidak ikutserta Jaminan Kesehatan Nasional dan 8 orang ikutserta Jaminan Kesehatan Nasional, dari 74 orang pendidikan menengah terdapat 10 orang tidak ikut serta Jaminan Kesehatan Nasional dan 64 orang ikutserta Jaminan Kesehatan Nasional, dan dari 8 orang pendidikan tinggi semuanya ikutserta Jaminan Kesehatan Nasional.

Berdasarkan hasil penelitian, Hasil uji Pearson Chi-Square didapat 
nilai $\chi^{2}=9,044$ dengan $\mathrm{p}$-value $=$ $0,011<0,05$ berarti signifikan, maka Ho ditolak dan Ha diterima, artinya ada hubungan antara pendidikan dengan keikutsertaan menjadi peserta Jaminan Kesehatan Nasional di Puskesmas Kembang Seri Bengkulu Tengah. Hal ini berarti semakin tinggi tingkat pendidikan seseorang, maka semakin besar kemungkinan seseorang dalam keikutsertaan Jaminan Kesehatan Nasional karena mereka menyadari pentingnya investasi kesehatan dengan mengikuti program Jaminan Kesehatan Nasional.

Hasil uji contingency coefficient didapat nilai $\mathrm{C}=0,293$ dengan $\mathrm{p}$-value $=0,011<0,05 \quad$ berarti signifikan. Nilai $\mathrm{C}=0,293$ tersebut dibandingkan dengan nilai $\mathrm{C}_{\max }=$ 0,707. Hasil yang didapat 0,414 terletak dalam interval 0,40-0,60 maka kategori hubungan sedang. Hal ini menunjukkan faktor keikutsertaan bukan hanya pendidikan namun juga disebabkan faktor lain diantaranya pengetahuan, pekerjaan serta pendapatan yang dapat mempengaruhi keikutsertaan Jaminan Kesehatan Nasional.

Hasil penelitian ini didukung oleh penelitian Puspitasari (2017) penelitian ini dilakukan di Desa Kasyan Timur pada 88 orang menunjukkan bahwa ada hubungan pendidikan dengan partisipasi kepesertaan JKN dengan pvalue $=0,000$. Dan didukung oleh penelitian Kurniawan (2018) penelitian ini dilakukan di Puskesmas Tamalanrea Jaya Kota makasar pada 100 responden, dengan hasil $\mathrm{p}$-value = 0,000 . Berarti terdapat hubungan antara pendidikan dengan keikutsertaan JKN.

Hasil ini sejalan dengan teori Anderson (1974) dalam Notoatmodjo (2012), Anderson menjelaskan sebagai salah satu faktor predisposisi tingkat pendidikan individu akan berpengaruh terhadap tindakan individu dalam pemanfaatan layanan kesehatan salah satunya keikutsertaan dalam JKN. Semakin tinggi tingkat pendidikan maka semakin besar kemungkinan seseorang dalam ikutserta dalam JKN. Menurut Anderson (1974) yang dikutip dari Notoatmodjo (2012) Tingkat pendidikan adalah salah satu karakteristik individu yang mempegaruhi seseorang dalam pemanfaatan pelayanan kesehatan. Tingkat pendidikan masyarakat sangat berpengaruh pada pola pikir masingmasing individu yang pada akhirnya membantu individu dalam ikutserta JKN.

Berdasarkan hasil di atas mengenai hubungan pengetahuan dengan keikutsertaan JKN menunjukkan bahwa dari total sampel 96 orang di Puskesmas Kembang Seri terdiri dari 61 orang yang memiliki pengetahuan baik terdapat 9 orang tidak ikut Jaminan Kesehatan Nasional dan 52 orang ikut Jaminan Kesehatan Nasional, dari 25 orang pengetahuan cukup terdapat 2 orang tidak ikut Jaminan Kesehatan Nasional dan 23 orang ikut Jaminan Kesehatan Nasional, dan dari 10 orang pengetahuan kurang terdapat 5 orang tidak ikut Jaminan Kesehatan Nasional dan 5 orang ikut Jaminan Kesehatan Nasional.

Hasil uji Pearson Chi-Square didapat nilai $\chi^{2}=9,513$ dengan $p$-value $=0,009<0,05$ berarti signifikan, maka Ho ditolak dan Ha diterima. Jadi ada hubungan antara pengetahuan dengan keikutsertaan menjadi peserta Jaminan Kesehatan Nasional di Puskesmas Kembang Seri Bengkulu Tengah. Hal ini berarti semakin tinggi tingkat pengetahuan seseorang tentang Jaminan Kessehatan Nasional (JKN), maka semakin besar kemungkinan seseorang dalam keikutsertaan Jaminan 
Kesehatan Nasional. Tingkat pengetahuan mempengaruhi seseorang ikutserta dalam Jaminan Kesehatan Nasional. Jika tingkat pengetahuan seseorang cukup baik tentang Jaminan Kesehatan Nasional maka mereka akan cenderung ikutserta dalam Jaminan Kesehatan Nasional.

Hasil uji contingency coefficient didapat nilai $\mathrm{C}=0,300$ dengan $\mathrm{p}$-value $=0,009<0,05$ berarti signifikan. Nilai $\mathrm{C}=0,300$ tersebut dibandingkan dengan nilai $\mathrm{C}_{\max }=$ 0,707 dengan hasil 0,424 karena nilai ini terletak dalam interval $0,40-0,60$ maka kategori hubungan sedang. Hal ini menunjukkan faktor keikutsertaan bukan hanya pengetahuan namun juga disebabkan faktor lain diantaranya pendidikan, pekerjaan serta pendapatan yang dapat mempengaruhi keikutsertaan Jaminan Kesehatan Nasional.

Hasil ini didukung oleh hasil penelitian Purwaningsih (2016) penelitian ini dilakukan di Desa Tegalsari Kabupaten Ponorogo untuk mengamati faktor-faktor keikutsertaan dalam Jaminan Kesehatan Nasional yang dilakukan dengan responden sebanyak 134 orang, dengan hasil 113 orang memiliki pengetahuan baik ikutserta dalam Jaminan Kesehatan Nasional dan 21 orang memiliki pengetahuan kurang tidak ikutserta dalam Jaminan Kesehatan Nasional. Pengetahuan yang tinggi dimungkinkan dipengaruhi oleh tingkat pendidikan. Menurut Gerungan (2004), semakin tinggi pendidikan akan jelas mempengaruhi pribadi seseorang dalam berpendapat, berfikir, bersikap dalam mengambil keputusan juga tindakan, termasuk dalam merencanakan kesehatan keluarganya salah satunya yaitu dengan mengikuti JKN. Hal ini didukung dengan penelitian Sastradimulya, dkk (2014), didapatkan distribusi tingkat pengetahuan responden tentang JKN kategori baik 37,5\%, cukup 28,33\%, kurang $34,1 \%$. Berarti terdapat hubungan antara pengetahuan dengan keikutsertaan JKN.

Hasil ini sejalan dengan Teori perilaku Green (1980) dalam Kholid (2014) menyebutkan bahwa pengetahuan merupakan salah satu faktor predisposing atau faktor yang mempengaruhi seseorang dalam kecenderungan terhadap sesuatu yang hasil akhirnya akan menghasilkan perilaku. Menurut Notoatmodjo (2012) pengetahuan merupakan domain yang sangat penting dalam membentuk suatu tindakan seseorang (overt behaviour). Jika seseorang didasari dengan pengetahuan yang baik terhadap kesehatan, maka seseorang tersebut akan memahami pentingnya menjaga kesehatan. Dengan semakin tingginya pengetahuan individu akan pentingnya kesehatan akan membuat individu sadar akan manfaat investasi kesehatan dalam bentuk Jaminan Kesehatan, sehingga akses terhadap pelayanan kesehatan lebih terjamin.

Berdasarkan hasil di atas mengenai hubungan pekerjaan dengan keikutsertaan JKN menunjukkan bahwa dari total sampel 96 orang di Puskesmas Kembang Seri terdiri dari 6 orang menunjukkan ekonomi tinggi terdapat 4 orang tidak ikutserta Jaminan Kesehatan Nasional dan 2 orang ikutserta Jaminan Kesehatan Nasional, dari 72 orang menunjukkan ekonomi sedang terdapat 12 orang tidak ikutserta Jaminan Keseahatan Nasional dan 60 orang ikutserta Jaminan Keseahatan Nasional, dan dari 18 orang menunjukkan ekonomi rendah semuanya ikut Jaminan Keseahatan Nasional. Hasil uji Pearson Chi-Square didapat nilai $\chi^{2}=14,4$ dengan $p$-value $=0,001<0,05$ berarti signifikan, maka 
Ho ditolak dan Ha diterima. Jadi Ada hubungan antara pekerjaan dengan keikutsertaan menjadi peserta Jaminan Kesehatan Nasional di Puskesmas Kembang Seri Bengkulu Tengah. Hal ini berarti jika seseorang memiliki pekerjaan tetap, maka semakin besar kemungkinan seseorang dalam keikutsertaan Jaminan Kesehatan Nasional.

Hasil uji Contingency Coefficient didapat nilai $\mathrm{C}=0,361$ dengan $\mathrm{p}$ value $=0,001<0,05$ berarti signifikan. Nilai $\mathrm{C}=0,361$ tersebut dibandingkan dengan nilai $C_{\max }=0,707$ dengan hasil 0,511 karena nilai ini terletak dalam interval 0,40-0,60 maka kategori hubungan sedang. Hal ini menunjukkan faktor keikutsertaan bukan hanya pekerjaan namun juga disebabkan faktor lain diantaranya pendidikan, pengetahuan, serta pendapatan yang dapat mempengaruhi keikutsertaan Jaminan Kesehatan Nasional.

Hasil ini didukung oleh hasil penelitian Kurniawan (2018) penelitian ini dilakukan di Puskesmas Tamalanrea Jaya Kota makasar dilakukan dengan responden sebanyak 100 orang, dengan hasil dari (p) sebesar 0,037. Berarti ada hubungan antara pekerjaan dengan keikutsertaan Jaminan Kesehatan. Pekerjaan seseorang dapat mempengaruhi dalam keikutsertaan jaminan kesehatan Nasional. Bekerja adalah salah satu upaya untuk mendapatkan pemasukan, sehingga dapat memenuhi kebutuhan dan meningkatkan kesejahteraan. Tingkat kesejahteraan yang baik dapat meningkatkan akses seseorang ke layanan kesehatan untuk menjaga status kesehatannya agar tetap baik (Indriyani, 2013).

Penelitian ini sejalan dengan teori Andersen (1974) dalam Babitsch, Daniela, \& Thomas (2012), pekerjaan merupakan salah satu variabel yang berpengaruh pada gaya hidup masyarakat dalam keikutsertaan Jaminan Kesehatan Nasional. Pekerjaan berperan dalam keikutsertaan Jaminan kesehatan karena jaminan kesehatan dari pekerjaan tersebut, penghasilan yang diperoleh dari pekerjaan tersebut, dan juga resiko yang ditimbulkan dari pekerjaan tersebut (Arifin, Soemadi, \& Setiawati, 2013). Menurut teori Green (1980) dalam Notoatmodjo (2012) status pekerjaan merupakan salah satu faktor predisposisi yang dapat mempengaruhi perilaku seseorang dalam pemanfaatan pelayanan kesehatan salah satunya keikutsertaan dalam Jaminan Kesehatan Nasional.

Berdasarkan hasil di atas mengenai hubungan pendapatan dengan keikutsertaan JKN menunjukkan bahwa dari total sampel 96 responden di Puskesmas Kembang Seri terdiri dari 24 orang memiliki pendapatan tinggi terdapat 8 orang tidak ikutserta Jaminan Kesehatan Nasional dan 16 orang ikutserta Jaminan Kesehatan Nasional. Dari 8 orang tersebut menyatakan tidak ikutserta JKN karna merasa prosedur dalam mengikuti JKN terlalu rumit dan juga mereka memiliki asuransi komersial lain seperti asuransi prudential, hal ini sejalan dengan penelitian Afifi (2009), menjelaskan bahwa pengeluaran rata-rata perbulan memiliki hubungan dengan kepemilikan asuransi komersial. Peserta yang memiliki asuransi merupakan mereka yang memiliki pendapatan tinggi yang mampu menyisihkan untuk mengikuti asuransi komersial lain. Ada 61 orang memiliki pendapatan sedang terdapat 8 orang tidak ikutserta Jaminan Kesehatan Nasional dan 53 orang ikutserta Jaminan Kesehatan Nasional. Serta 11 responden memiliki pendapatan rendah 
semuanya ikutserta Jaminan Kesehatan Nasional. Hasil uji Pearson Chi-Square didapat nilai $\chi^{2}=7,554$ dengan $p$ value $=0,023<0,05$ berarti signifikan, maka Ho ditolak dan Ha diterima. Jadi Ada hubungan antara pendapatan dengan keikutsertaan menjadi peserta Jaminan Kesehatan Nasional di Puskesmas Kembang Seri Bengkulu Tengah. Hal ini berarti semakin tinggi pendapatan seseorang, maka semakin besar kemungkinan seseorang dalam keikutsertaan Jaminan Kesehatan Nasional.

Hasil uji contingency coefficient didapat nilai $\mathrm{C}=0,270$ dengan $\mathrm{p}$ value $=0,023<0,05$ berarti signifikan . Nilai $\mathrm{C}=0,270$ tersebut dibandingkan dengan nilai $\mathrm{C}_{\max }=0,707$ dengan nilai 0,382, karena nilai ini terletak dalam interval 0,20-0,40 maka kategori hubungan lemah. Hal ini menunjukkan faktor keikutsertaan bukan hanya pendapatan namun juga disebabkan faktor lain diantaranya pendidikan, pengetahuan, serta pekerjaan yang dapat mempengaruhi keikutsertaan Jaminan Kesehatan Nasional.

Hasil ini didukung oleh hasil penelitian Purwaningsih (2016) penelitian ini dilakukan di Desa Tegalsari Kabupaten Ponorogo untuk mengamati faktor-faktor keikutsertaan dalam Jaminan Kesehatan Nasional yang dilakukan dengan responden sebanyak 134 orang, dengan hasil bahwa ada hubungan yang signifikan antara penghasilan dengan keikutsertaan kepala keluarga dalam jaminan kesehatan nasional dengan $\mathrm{p}$ value $=0,027$. Didukung oleh penelitian Puspitasari (2017), yang menunjukkan ada hubungan antara pendapatan dengan keikutsertaan JKN dengan pvalue $=0,042$.

Penelitian ini sejalan dengan teori Green (1980) dalam Notoatmodjo (2012) status pendapatan merupakan salah satu faktor predisposisi yang dapat mempengaruhi perilaku seseorang dalam keikutsertaan Jaminan Kesehatan. Sumardi (2007), menjelaskan bahwa pendapatan yang diterima oleh penduduk dipengaruhi oleh tingkat pendidikan yang dimilikinya. Dengan pendidikan yang tinggi mereka akan dapat memperoleh kesempatan yang lebih luas untuk mendapatkan pekerjaan yang lebih baik disertai pendapatan yang lebih besar. Sedangkan penduduk yang berpendidikan rendah akan mendapat pekerjaan yang lebih kecil.

\section{E. Kesimpulan}

1. Dari 96 orang, 74 orang $(77,1 \%)$ memiliki pendidikan menengah, 61 orang $(63,5 \%) \quad$ memiliki pengetahuan baik, 72 orang $(75,0 \%)$ menunjukkan pekerjaan dengan status ekonomi sedang, 61 orang $(63,5 \%)$ tingkat pendapatan sedang, dari hasil tersebut terdapat 80 orang $(83,3 \%)$ ikut serta JKN .

2. Ada hubungan yang signifikan antara tingkat pendidikan dengan keikutsertaan Jaminan Kesehatan Nasional di Puskesmas Kembang Seri Kabupaten Bengkulu Tengah dengan kategori hubungan sedang.

3. Ada hubungan yang signifikan antara tingkat pengetahuan dengan keikutsertaan Jaminan Kesehatan Nasional di Puskesmas Kembang Seri Kabupaten Bengkulu Tengah dengan kategori hubungan sedang.

4. Ada hubungan yang signifikan antara pekerjaan dengan keikutsertaan Jaminan Kesehatan Nasional di Puskesmas Kembang Seri Kabupaten Bengkulu Tengah dengan kategori hubungan sedang.

5. Ada hubungan yang signifikan antara pendapatan dengan keikutsertaan Jaminan Kesehatan Nasional di Puskesmas Kembang 
Seri Kabupaten Bengkulu Tengah dengan kategori hubungan lemah.

\section{Daftar Pustaka}

Afifi A. (2009). Faktor-faktor yang berhubungan dengan kepemilikan asuransi komersial. Skripsi. Universitas Indonesia. Diakses 11 juni 2019 dari

http://lib.ui.ac.id/file?file=digit al/124274-S-5715-Faktorfaktor\%20yang-HA.pdf

Arifin, B. S., Soemadi, W., \& Setiawati, F. (2013). Pemanfaatan Fasilitas Jaminan Kesehatan Masyarakat dalam Bidang Kesehatan Gigi dan Mulut di Puskesmas Kecamatan Cimanggis Kota Depok Jawa Barat Tahun 2012. Skripsi. Universitas Indonesia. Diakses 11 Juni 2019 dari http://lib.ui.ac.id/naskahringkas/ 2015-09/S44202Bey\%20Johan\%20Arifin

Babitsch, B., Daniela, G., \& Thomas V. L. (2012). Re-revisiting Andersen's Behavioral Model of Health Services Use: a systematic review of studies from 1998-2011. GMS PsychoSocial-Medicine, 9, 1-15. Diunduh dari https://www.egms.de/static/en/j ournals/psm/20129/psm000089.shtml

Badan Pusat Statistik (BPS) Kabupaten Bengkulu Tengah. (2018). Profil Penduduk Bengkulu Tengah 2017. Diakses pada tanggal 01 Desember 2018 dari https://bengkulutengahkab.bps. go.id/

Badan Penyelenggara Jaminan Sosial (BPJS) Kesehatan. (2018). Profil BPJS Kesehatan. Diakses pada tanggal 02 Desember 2018 dari https://bpjs-

kesehatan.go.id/bpjs/

Dinas Kependudukan dan Catatan Sipil (Dukcapil). (2017). Profil jumlah penduduk bengkulu 2017. Bengkulu: Dinas Kependudukan dan Catatan sipil Bengkulu

Gerungan. (2004). Psikologi sosial. Bandung: PT Refika Aditama

Indriyani. (2013). Analisis FaktorFaktor yang Berhubungan dengan Utilisasi pelayanan Persalinan oleh Pasien Antenatal Care di Rumah Sakit Puri Cinere Tahun 2013. Skripsi. Universitas Islam Negeri Syarif Hidayatullah. Diakses 13 November 2018 dari http://repository.uinjkt.ac.id/dsp ace/bitstream/123456789/26512 /1/INDRYANI-FKIK.pdf

Kholid, A. (2014). Promosi Kesehatan dengan pendekatan Teori Perilaku, Media dan Aplikasinya. Jakarta : Rajawali Pers

Kurniawan, D. (2018). Faktor faktor yang mempengaruhi masyarakat dalam Pemanfaatan jaminan kesehatan nasional di wilayah Kerja puskesmas tamalanrea jaya Kota Makassar. Skripsi. Universitas Hasanudin. Diakses pada tanggal 13 November 2018 dari http://digilib.unhas.ac.id/upload ed_files/temporary/DigitalColle ction/MzFmYTZiMTZiNjM2Zi IxNzFiNWI0YjEwYzhiNDE0Z jAyMmJjMjRmYQ==.pdf

Notoatmodjo, S. (2012). Ilmu Perilaku Kesehatan. Jakarta: Rineka Cipta.

Putri, A. E. (2014). Paham JKN Jaminan Kesehatan Nasional. 
Jakarta: Friedrich Ebert Stiftung

Purwaningsih, S.B. (2016). FaktorFaktor yang Berhubungan dengan Keikutsertaan Masyarakat dalam Jaminan Kesehatan Nasional di Desa Tegalsari Kabupaten Ponorogo 2016. Fakultas Ilmu Kesehatan Universitas Muhammadiyah Surakarta. Diakses pada tanggal 11 November 2018 dari http://eprints.ums.ac.id

Puspitasari, Y. (2017). Faktor yang Mempengaruhi Partisipasi Kepesertaan Jaminan Kesehatan Nasional Pada Pekerja Bukan Penerima upah di desa Kasiyan Timur wilayah kerja Puskesmas Kasiyan Kabupaten Jember Tahun 2016. Skripsi. Universitas Jember. Diakses pada tanggal 28 November 2018 dari http://repository.unej.ac.id

Puskesmas Kembang Seri. (2018). Laporan Jumlah Peserta JKN 2018. Bengkulu Tengah: Puskesmas Kembang Seri

Kemenkes RI. (2018). Hasil utama Riskesdas 2018. Diakses pada tanggal 24 Desember 2018 dari http://www.kesmas.kemkes.go.i d/assets/upload/dir_519d41d8cd 98f00/files/Hasil-riskesdas2018_1274.pdf

Kemenkes RI. (2016). Survei Indikator Kesehatan Nasional. Jakarta.
Diakses pada tanggal 24 Desember 2018 dari http://www.labdata.litbang.dep kes.go.id.

Kemenkes RI. (2013). Hasil utama Riskesdas 2013. Diakses pada tanggal 24 Desember 2018 dari https://pusdatin.kemkes.go.id/re sources/download/general/Hasil \%20Riskesdas\%202013.pdf

Sastradimulya, F. Nurhayati, E \& Susanti, Y. (2014). Hubungan tingkat pengetahuan pasien tentang jaminan kesehatan nasional dengan status kepesertaan BPJS. Prosiding Pendidikan Dokter, 2, 578-583. Diunduh dari http://karyailmiah.unisba.ac.id/i ndex.php/dokter/article/downlo ad/1431/pdf

Sumardi, M. (2007). Kemiskinan dan Kebutuhan Pokok. Jakarta: Rajawali

WHO. (2016). Global Health Observatory (GHO): World Health Organization. Diakses pada tanggal 24 Desember 2018 dari https://www.who.int/

World Economis Forum. (2015). The Global Competitiveness Report 2015. Diakses Pada Tanggal 24 Desember 2018 dari https://www.weforum.org/repor ts/global-competitivenessreport-2015 